\title{
Institutional persistence despite cultural change: a historical case study of the re-categorization of dogs in Germany
}

\author{
Birgit Pfau-Effinger ${ }^{1}$ (D) Marcel Sebastian $^{1}$ (D
}

Accepted: 25 September 2021 / Published online: 8 November 2021

(c) The Author(s) 2021

\begin{abstract}
Human-animal relations in post-industrial societies are characterized by a system of cultural categories that distinguishes between different types of animals based on their function in human society, such as "farm animals" or "pets." The system of cultural categories, and the allocation of animal species within this cultural classification system can change. Options for change include re-categorizing a specific animal species within the categorical system. The paper argues that attempts by political actors to adapt the institutional system to cultural change that calls for re-categorization of certain animal species can start a contradictory process that may lead to long-term survival of the respective institution despite the cultural change. It is common to explain the persistence of political institutions with institutional path dependency or policy preferences of the governing parties. This paper introduces a new institutional theoretical approach to the explanation, the approach of "rejecting changing a part for fear of undermining the whole." This paper uses a case study of a series of failed political efforts to change the treatment of dogs in the framework of the agricultural human-animal policy in the Federal Republic of Germany in the second half of the twentieth century, to evaluate its theoretical argument, using analyses of historical political documents, mass media, and communication documents between civil society actors and policymakers. This paper makes an innovative contribution to the theory and research on institutional change, the sociology of agriculture and food, and the sociology of human-animal relations.
\end{abstract}

Keywords Institution theory $\cdot$ Institutional persistence $\cdot$ Cultural change $\cdot$ Agricultural policy $\cdot$ Human-animal relations

\section{Introduction}

This article focuses on the influence of cultural ideas on institutional change in welfare states. It examines why it is possible for an institution to remain stable in the long term although it is under great pressure to make adjustments as a result of a cultural change within the population. It is common to explain the persistence of political institutions with institutional path dependency or policy preferences of the governing parties. However, this paper introduces a new institutional theoretical approach to the explanation, which is not covered by these common views.

Birgit Pfau-Effinger

pfau-effinger@uni-hamburg.de

Marcel Sebastian

kontakt@marcelsebastian.de

1 Department of Social Sciences, University of Hamburg, Allende Platz 1, 20146 Hamburg, Germany
"Culture" is defined in this paper as a system of collective ideas related to the idea of a good society and morally good behavior. Cultural ideas comprise cultural values, models and belief systems. The ideas can be coherent or contradictory, contested between social groups and actors, and they can change (Archer 1996; Pfau-Effinger 2005). Based on an institutional theoretical approach rooted in Historical Institutionalism, the paper defines an "institution" as a set of rules that frame the actions of social actors based on incentives and restrictions. The rules must be implemented (institutionalized) and legitimate. Compliance with the rules is reinforced with sanctions. In this sense, a law is a typical institution (Hall and Taylor 1996; Pierson 2001). Institutions rest on norms that determine what kinds of behaviors are expected within the boundaries set by the institution (Frericks 2017; Hall 1993). The content of such norms is influenced by cultural ideas. However, it is important to consider that cultural ideas in the population and those in institutions can change at different speeds, which can lead to 
a "cultural" or an "institutional" lag (Ogburn 1964; Archer 1996; Pfau-Effinger 2005).

The argument in this article is based on an analysis of agricultural human-animal policies. Human-animal relations in post-industrial societies are characterized by a system of cultural categories that distinguishes between different types of animals according to their function in human society, such as "farm animals" or "pets." Cultural ideas about "adequate" treatment of animals vary among cultural categories (Sebastian 2019; Morgan and Cole 2011). In modern post-industrial societies, these cultural categories are the basis of political institutions that define the legal treatment of each of these categories of animals. This classification is not static, because the system of cultural categories, as well as the allocation of animal species within this cultural classification system, can change. Options for change include the re-categorization of a specific animal species within the categorical system from a less protected category to a more protected one, for instance, from the category of "livestock animals" to the category of "pets" (Sebastian 2021).

The article argues that attempts by political actors to adapt the institutional system to cultural change that calls for re-categorization of certain animal species can start a contradictory process that may lead to long-term survival of the institution despite the cultural change. To explain this, the paper introduces a new institutional theoretical approach, the approach of "rejecting changing a part for fear of undermining the whole." 10 evaluate this theoretical argument, the paper uses a case study of dogs in the animal protection policy of the Federal Republic of Germany in the second half of the twentieth century. Dogs provide a particularly suitable case for analyzing conflicts regarding cultural and institutional categorization of animals, as dogs are the most popular pet species in many advanced Western societies, including Germany, and poor treatment of dogs by private pet owners or in animal experiments regularly leads to public debates (Arluke 2006; Grier 2006; Franklin 1999). In this respect, that killing dogs for food production was legalized in Germany by the Meat Inspection Act until 1986 is remarkable and requires an explanation.

Traditionally, it was common to categorize dogs mainly as "farm animals," and people accepted that they were killed and the meat used for human consumption. Accordingly, in the Meat Inspection Act of 1900, which remains the relevant institutional framework that regulates which animals are constructed as "slaughter animals," dogs were included in the list of animals institutionally categorized as "animals

\footnotetext{
${ }^{1}$ We owe this term to the very helpful comments of a reviewer for Agriculture and Human Values regarding a previous version of this paper, for which we would like to thank the reviewer.
}

for slaughter," together with cattle, pigs, rabbits, goats, and horses. This classification was maintained despite several revisions of the act. However, during the urbanization of the country beginning in the early twentieth century, cultural categorization of dogs as "pets" in family households became increasingly popular. Because of this cultural shift, most Germans rejected the killing of dogs for the purpose of consumption as meat in the early 1950s, and a broad popular movement, supported by popular mass media, demanded a ban on such practices. Consequently, several bills to ban the killing of dogs for meat were initiated beginning in 1954. The first four failed, but the fifth was successful in 1986, after 32 long years. This paper analyzes why the first four failed, and the fifth one succeeded. In addition to the main theoretical assumptions, which explain institutional persistence with the political dilemma that can be the result of inconsistent cultural pressure on an institution, the paper examines the significance of competing explanatory approaches, such as the path dependency and party preference theories.

The paper is innovative as it offers a new insight into the theory and research on historical institutionalism based a new theoretical approach to explaining institutional persistence. The paper also contributes to theorizing and research in the sociology of agriculture and food, as well as the sociology of human-animal relations about relevant conditions for persistence and the change in the institutional framework for the distinction between slaughter animals and other, more protected categories of animals.

Section 2 provides an overview and discussion of the theory and research on the relationship between culture and institutional change in public policies. Section 3 introduces the theoretical approach of the paper, and Sect. 4 explains the methodological approach. In Sect. 5, the results of the historical analysis are presented and discussed. Section 6 provides conclusions.

\section{State of theorizing about and research on change in political institutions}

\section{Assumption of the persistence of institutions}

Because institutions have a central role in maintaining social order, institutional theory generally considers them relatively stable (North 1990). Scholars of path dependence theory assume that institutions can exhibit a high degree of persistence and retain essential characteristics as they develop, even if they no longer fulfill their function adequately. The theoretical approach of path dependency is based on the assumption that the past exerts a strong influence on the development of institutions (Arthur 1994; David 1985). Thus, self-reinforcing processes 
("increasing returns") are an essential condition for institutional path dependency. According to scientists who use this approach, increasing returns are caused by an increase in the number of institutions that surround an institution and complement it in their functioning (David 1985; Pierson 2001). Therefore, the transaction costs that would be incurred if these institutions were abandoned increase with the duration of the respective institution. Therefore, institutional stability increases with the duration of the institution (North 1990; Pierson 2001). According to Paul Pierson (2001), the development of political institutions in particular is often characterized by path dependency.

However, the path-dependence theory is contested. Some authors found that different continuity-ensuring mechanisms can be relevant, and they therefore question the explanatory power of this approach (Ebbinghaus 2005). Jürgen Beyer (2010) therefore argues that it would be important to analyze the various mechanisms which are underlying institutional persistence.

\section{Culture and the development of political institutions}

In the common theoretical approaches that explain changes in public policies and the institutions on which the policies are based, various factors that contribute to change have been discussed (see Capano 2009), which include the role of cultural ideas (Pfau-Effinger 2005; Béland 2009; Danielson and Stryker 2015; Frericks 2017). For example, it has been shown that conflicts between representatives of different world views, especially between conservatives, liberals, and socialists, have contributed significantly to the emergence of the Western welfare states in their current form (Esping-Andersen 1990).

Some theories and research, mainly in political science, are interested in the way cultural ideas enter the political process. According to Daniel Béland (2009), they do so in different stages of the political decision-making process. Vivien Schmidt (2002) pointed out that political elites often initiate political and public discourses outside the political arena to gain public approval for their policies and thus, legitimize them. Birgit Pfau-Effinger (2005) argued that cultural change can also originate from changes in the cultural ideas of the population outside the political arena. If powerful actors such as social movements initiate public discourses based on the new popular ideas, this may put pressure on the actors in the political arena to make adjustments to the respective institution. However, approaches that explain why institutions can persist despite strong external pressures and despite not being embedded in a network of corresponding institutions are lacking.

\section{Research on the conditions for change in the institutional framework for the human- animal relationship}

Researchers have also explored change in the institutional framework for the human-animal relationship. A significant part of this research addresses the question how and under which conditions institutional change in animal protection laws can be achieved. The analysis focuses mainly on laws protecting animals from harm and preventing animal cruelty (see Cao and White 2016; Peters 2020; Wise 2003). Scholars have criticized existing legal regulations on the human-animal relationship as inherently ambivalent because they simultaneously express moral concern for animals and hold far-reaching power of disposal over them (e.g., Stucki 2017).

There is also research on institutional change in slaughter laws, specifically public debates about religious forms of slaughter (e.g., Wills 2020). Institutional change in religious slaughter concerns the prohibition of certain killing practices, not of slaughter as such. Dog meat consumption has been mainly discussed as a contemporary cultural controversy in countries where dogs traditionally were consumed regularly, such as China (see Li et al. 2017) and South Korea (see Oh and Jackson 2011). However, there is a gap in research on the conditions under which the institutional framework that allows social practices such as dog slaughter persist or are changed. Furthermore, little research has been conducted on the conditions for change in the allocation of animals within the system of animal categories in the institutional regulations about animals, especially regarding political institutions that frame agriculture and food safety.

\section{Theoretical and analytical framework of the study}

This paper argues that cultural change in the population, related to an institution, can take place relatively independent from the development of the institution, even if the institution itself remains stable. A massive cultural change in the population can lead to pressure on the institution to change. This is particularly the case when actors carry cultural ideas that have become popular into the political arena and thus, "politicize" the issue (Börzel and Risse 2009). However, it is important to consider that such pressure does not necessarily lead to a corresponding institutional change. This paper examines why it is possible for an institution to remain stable in the long term although it is under great pressure to make adjustments as a result of cultural change within the population.

This paper introduces a new institution theoretical approach, which is not covered by such common views: "rejecting changing a part for fear of undermining the 
whole." It is argued that pressure for change that affects only specific elements of the institution's regulations, while the legitimacy of the institution as a whole is not questioned, can lead to relevant actors avoiding institutional change. This effect is based on the following causal mechanism: Because the new cultural ideas affect only specific elements of the institution they are related to, the political actors may find themselves in a dilemma of action, which is caused by a partial institutional change that could lead to a questioning of the legitimacy of the institution as a whole. Thus, the likelihood that a contradictory approach to a change in this institution would emerge in the political arena increases. The main actors initiate strong and publicly visible political approaches to set up institutional change based on broad political consensus. However, "behind the curtain" in the political arena, institutional change is hindered.

This paper examines political institutions that provide regulations for individuals or elements that belong to a specific category and define which types of people or elements belong to this category, and which type of treatment of the individuals or elements of this category is legal and legitimate. These institutional regulations are usually based on cultural classification systems that distinguish between different categories based on cultural values (Steensland 2006). Researchers investigating society's relationship with animals have pointed out that, typically, society culturally distinguishes between different categories to which specific animal species are assigned—such as "pets," "farm animals," and "wild animals." Different forms of animal treatment are considered legitimate for different categories of animals (Sebastian 2019; Morgan and Cole 2011), and different political institutions regulate the treatment of each category. For example, agriculture ministries are responsible for the institutions that regulate how farm animals can be treated.

It is common to explain the persistence of political institutions with the institutional path dependency or policy preferences of the governing parties approach. Therefore, in addition, this paper evaluates the role of the explanation that uses the path dependency approach based on "increasing returns" and of the explanation that uses the political preferences of the governing political parties.

Exploring the role of the path dependency approach, this paper evaluates how long it is possible to explain the persistence of an institution despite pressure to change. In other words, it explores how long the institution experienced a self-reinforcing process of "increasing returns." James Mahoney (2000) distinguished between four different social mechanisms on which "increasing returns" processes can be based. The mechanisms include utilitarian causes, if the actors maintain the institution based on cost-benefit considerations; functional causes, if the respective institution is relevant for the functioning of an overarching system.
"Increasing returns" can also be based on power, if path dependence aims to maintain the power of an elite group of actors; and on legitimizing reasons, if the actors feel a moral duty to maintain the institution.

In exploring the role of the party preferences approach, the political orientation of government parties on the right-left spectrum provides a relevant contribution to explaining differences in policies (Allan and Scruggs 2004; Hibbs 1977). According to this approach, leftist governments tend to promote institutional change based on the interests of low-income classes and egalitarian ideas, whereas conservative parties support institutional change based on the interests of high-income classes and hierarchical inequality. On this basis, one might expect that left-wing governments involving social democratic and/or "green" parties would be likely to promote policies that re-categorize certain animal species from "slaughter animals" to "pets." The assumptions on the relationship between the political preferences of the governing parties and policies have been contested in some cases (Häusermann et al. 2013). For example, social democratic parties in European welfare states have often carried out political reforms that tended to be based on neoliberal ideas (Gingrich 2011). Nevertheless, party preference theory still represents a relevant explanatory approach for analyzing political change (Häusermann et al. 2013).

\section{Methodological approach to the historical case study}

These theoretical assumptions are evaluated with a case study that examines the reasons and relevant mechanisms for why the slaughter of dogs was not prohibited by law in Germany until 1986. The specific part of the Meat Inspection Act that allowed the killing of dogs had not received any cultural support from large segments of the population since the early 1950s. Moreover, since then, abolition of the regulation had been demanded by a strong animal protection movement.

The analyzed period spans the beginning of the political discussion of the killing of dogs for consumption in 1951 until the institutional reorganization in 1986. To answer the research question of this paper, historical political documents in the "Bundesarchiv" (in brief: BArch) (Federal Archives in Koblenz, Bundestag), in the "Bundestagsarchiv" (in brief DBArch) (Parliament Archive) and in the Bundesrat Archive (in brief: BRArch) (Archives of Federal Council) were analyzed. These policy documents offer adequate data for the study as they aid the analysis of the processes that led to the decision-making of the main actors in the political process. The documents included the five relevant bills that were introduced in the Bundestag or Bundesrat (the lower and upper chambers of the German parliament, 
respectively) by the federal government and a state government between 1954 and 1985. They also included minutes of parliamentary sessions, committee meetings, meetings within the participating ministries, and federal governments, as well as communications written by members of the German government, federal ministries, and civil society. The analysis of changes in cultural ideas related to the killing and consumption of dogs was based on the analysis of publications in selected mass media outlets regarding public debates on the dog meat ban, and of historical documents covering written communication between actors in civil society and politicians.

Using the process tracing method (Beach and Pedersen 2013), the processes relevant for institutional persistence despite the strong cultural pressure for change were reconstructed. Furthermore, the reasons that the fifth submitted bill finally led to institutional change are analyzed. The process tracing method identifies the causal mechanisms or the chain of events on which a causal relationship between an explanatory variable and a dependent variable is based. The mechanisms include the logical steps that produce the causal effect (Trampusch and Palier 2016). An individual case study is an adequate method for analyzing causal mechanisms. It can provide "persuasive causal explanations" (Rueschemeyer 2003) for a particular social phenomenon if it is possible to identify and explain the causal mechanism behind the effect of a variable on an outcome.

\section{Results of the historical case study of Germany}

\section{Cultural change and the pressure to ban the slaughter of dogs}

The Meat Inspection Act of 1900 regulated which types of animals were defined as "slaughter animals" that could be killed for consumption. This category comprised substantial parts of all types of animals that were categorized as "farm animals." Dogs were referred to as "slaughter animals" in the law, in addition to cattle, pigs, sheep, goats, rabbits, horses, and donkeys. The institutional definition of dogs as "slaughter animals" resonates with the categorization of dogs as "farm animals." Especially in rural regions of Germany, dogs were used to guard farms and small craft enterprises, as herding animals, or for hunting. The Nazi regime did not repeal the Meat Inspection Act, and the law was later largely adopted in its previous form by the Federal Republic of Germany after the Second World War (see Pluda 2019).

With the sharp decline in the proportion of people working in agriculture (see Mai 2007) and the emergence of a broad urban middle class in the context of the development of the industrial society, dogs were increasingly integrated in family households and shown affection (Blouin 2012; Franklin 1999; Grier 2006), corresponding to a general trend in Western societies. Consequently, it was increasingly common in the German population to classify dogs solely as "pets". The change in the cultural categorization of dogs sharply contradicted the institutional categorization of dogs as "slaughter animals" or "farm animals," and by the 1950s, the latter was no longer accepted by the population. The function of dogs as herding dogs or guard dogs in agricultural contexts became increasingly less relevant in postwar Germany. Other functions included and still include use as guard dogs in the private and public security sector as well as use in animal experiments. There are no comprehensive statistical data on the number of dog slaughters in Germany, but regional statistics indicate that in the 1950s, consumption of dog meat was rare; fewer than 100 cases per year were reported. In the 1980s, consumption of dog meat was almost unheard of (Geppert 1990). A broad segment of German culture rejects consuming dog meat. This distinguishes the case from cultural controversies in countries where there is substantial support for consuming dog meat, such as China (see Li et al. 2017) and South Korea (see Oh and Jackson 2011).

As a result of this cultural change, relevant animal protection organizations and most of the German population publicly demanded that killing dogs for consumption be prohibited and exerted strong pressure on the German federal government and responsible ministries through petitions and protest letters (Sebastian 2021). This campaign echoed within the population, especially as it was supported by the new Bild newspaper. In the 1950s and 1960s, leading politicians spoke out publicly in favor of a ban, including President Theodor Heuss, ${ }^{2}$ Federal Minister of the Interior Gerhard Schröder, ${ }^{3}$ Federal Minister of Food, Agriculture and Forestry Heinrich Lübke, ${ }^{4}$ Chairman of the FDP (Free Democratic Party) parliamentary group Erich Mende, ${ }^{5}$ and members of the Bundestag. ${ }^{6}$ Although agribusiness interest groups normally play a significant role in formulating policy changes regarding animal welfare, meat industry lobbying organizations did not attempt to influence the ban on dog meat production during the period investigated. On the contrary, even the Bavarian Cattle Dealers Association and

\footnotetext{
${ }^{2}$ BArch, File B116/4630, letter from November 8, 1955; BildZeitung, January 29, 1954, No. 24, "Auch Heuss bedauert HundeSchlachtungen".

3 Protocol of the 26th Meeting of the 2nd German Bundestag, April 29, 1954, DBArch.

${ }^{4}$ Bild-Zeitung, January 15, 1954, No. 12, p. 1, "Hunde-Debatte im Bundestag".

5 Bild-Zeitung, January 15, 1954, No. 12, p. 1, "Hunde-Debatte im Bundestag".

${ }^{6}$ BArch, File, B116/4630, note from March 11, 1954.
} 
two slaughterhouse managers expressed their support publicly. The main reason could be that there was never a clear economic interest in the production of dog meat (Sebastian 2021).

\section{Overview of the legislative initiatives}

Due to the cultural change, it could be expected that a ban on the consumption of dog meat would have been introduced quickly. However, killing dogs for food was not prohibited for 32 more years. During this period, four initiatives for institutional change failed: an initiative by the German Party in 1954, two initiatives by the federal government in 1959 and 1963, and one by the government of the state of Hesse in 1985. A fifth initiative, by the Bundestag Committee for Youth, Family and Health, finally led to a ban on the killing of dogs for food in 1986. The development and political treatment of the four unsuccessful initiatives is explained below.

\section{First Initiative (1954)}

Triggered by protests by the animal protection movement and the population, the killing of dogs for consumption was first discussed in 1951 within the Federal Ministry of Agriculture. In 1954, the German Party, which was part of the governing coalition, submitted a bill to the German Bundestag to ban the sale of dog meat. ${ }^{7}$ Shortly afterward, the issue was also discussed in the Bundestag during a Q\&A session. A bill drafted by the German Party was sent to the Bundestag Committee for Nutrition, Agriculture and Forestry, which decided, after a short consultation, not to pursue the proposal further. The committee argued that a ban on the sale of dog meat was not comprehensive enough. As the bill proposed to ban only the sale and not the consumption of dog meat, the bill did not meet the public desire to ban the killing of dogs for food. ${ }^{8}$

\section{Second Initiative (1959)}

After the first bill was rejected, animal protection organizations continued to protest. The Federal Ministry of Agriculture, the Federal Ministry of Justice, and the Federal Ministry of the Interior discussed additional possibilities for a more comprehensive bill prohibiting killing dogs for consumption. In 1959, the German federal government (CDU/

\footnotetext{
7 Bundestag-Drucksache Nr. 02/415, DBArch.

${ }^{8}$ BArch, File B116/4630, notes from the 25th Meeting of the Bundestags-Committee for Nutrition, Agriculture and Forestry, June 22, 1954.
}

CSU) sent a bill to the Bundesrat. ${ }^{9}$ This bill was accepted and passed on to the Bundestag, which, in turn, passed the bill to the Legal Committee, on January 20, $1960 .{ }^{10}$ According to an employee of the Federal Ministry of Agriculture, however, the bill could not be conclusively discussed in the Legal Affairs Committee because it was the end of the legislative period. ${ }^{11}$

\section{Third Initiative (1963)}

In 1963, the federal government (CDU/CSU/FDP) introduced a bill, identical to that of 1959 , in the Bundesrat, ${ }^{12}$ which rejected it, ${ }^{13}$ following the recommendation of the Legal Committee. ${ }^{14}$ Above all, the committee criticized that the bill permit the killing of dogs for other reasons, such as the production of cosmetics or fur products. This implied that proving possible perpetrators killed dogs for food production and not for other purposes was a problem. According to the objections, this problem would complicate implementation of the law. ${ }^{15}$

\section{Fourth Initiative (1985)}

Twenty years passed before prohibiting the killing of dogs for consumption was attempted. Meanwhile, protests against slaughtering dogs had expanded. In addition to animal protection organizations, German veterinarians publicly questioned the legality of killing dogs for food production. ${ }^{16}$ After civil society organizations' protests intensified, a lively discussion began again within the federal government. In 1985 , before the German federal government could propose a law, the SPD-ruled state of Hesse introduced a bill to the Bundesrat. ${ }^{17}$ Why the state of Hesse introduced this initiative cannot be inferred from the empirical data. This bill also failed in the Bundesrat committees, which recommended rejection by a narrow majority. ${ }^{18}$ The rejection was justified

\footnotetext{
$\overline{9}$ Bundesrat-Drucksache Nr. 309/59, BRArch.

${ }^{10}$ Protocol of the 95th Meeting of the 3rd German Bundestag, January 20, 1960, DBArch.

${ }^{11}$ BArch, File 116/50101, note from August 2, 1962.

12 Bundesrat-Drucksache 432/63, BRArch.

13 Protocol of the 261st Meeting of the German Bundesrat, October 25, 1963, BRArch.

14 BArch, File B 116/50101, note from October 16, 1963.

15 BArch, File 116/50101, protocol of the 267th Meeting of the Bundesrat Legal Committee October 16, 1963.

${ }^{16}$ For example, BArch, File B189/31451, letter from November 20, 1984.

17 Bundesrat-Drucksache Nr. 183/85, BRArch.

18 Protocols of: 550th Meeting of the Bundesrat Legal Committee, May 29, 1985, BRAch; 229th Meeting of the Bundesrat Committee for Youth, Family and Health, May 30, 1985, BRArch; 454th Meeting of the Bundesrat Committee for Agriculture, June 3, 1985, BRArch;
} 
by worries among the main political actors that a ban on killing dogs for consumption would be extended to other animals classified as "slaughter animals." 19 Therefore, the Bundesrat also rejected the bill. ${ }^{20}$

\section{Institutional persistence between 1954 and 1985}

This section discusses how the findings of the case study support our theoretical approach of "rejecting changing a part for fear of undermining the whole."

\section{The interaction between cultural and institutional factors}

First, this paper examines the main assumption that the inconsistent pressure for change which arose as a result of cultural change and did not address the institution Meat Inspection Act as a whole but only an element of it makes a significant contribution to understanding why the institution remained stable. The analysis of the documents showed that all four bills introduced were based on a moral argument. This was justified by the shift in the cultural categorization of dogs from "farm animals" solely to "pets." Although written justification for the first bill cannot be found in the files of the Bundestag archives, ${ }^{21}$ the proposal clearly corresponded to the ongoing public criticism of dog meat consumption. The Bild newspaper stated that the German Party explicitly referred to the newspaper's campaign against slaughtering dogs in the party's motion for a prohibition on dog meat sales. ${ }^{22}$ Moreover, a 1958 memorandum includes a note that the German Party had submitted the bill at the suggestion of the Tierschutzbund, Germany's largest animal welfare organization. ${ }^{23}$ The next two bills (1959 and 1963) argued that dogs held a special position because of "their inclusion in the closer circle of humans." ${ }^{24}$ Therefore, killing dogs for consumption would be considered, by the majority of the population, "highly offensive and contrary to human and moral sentiment." ${ }^{25}$ The state of Hess's 1985 bill took up this argument and insisted that such killings were "no longer

Footnote 18 (continued)

552nd Meeting of the Bundesrats Legal Committee, June 19, 1985, BRArch; Bundesrat-Drucksache Nr. 183/1/85, BRArch.

19 Ibid.

20 Protocol of the 553rd Meeting of the German Bundesrat, July 5, 1985, BRArch.

21 Bundestag-Drucksache Nr. 02/415, DBArch.

22 Bild-Zeitung, March 3, 1954, No. 79, p. 1, "Gesetzentwurf gegen das Hundeschlachten “.

23 Bundestag-Drucksache Nr. 03/1485, DBArch.

24 BArch, B136-/8666, note from March 12, 1958.

25 BArch, B136-/8666, note from March 12, 1958. acceptable for ethical reasons." ${ }^{26}$ The moral foundation of these bills prohibiting killing of dogs for consumption was shared by all participants in German politics between 1954 and 1985. No actors in the German political arena or in civil society advocated the consumption of dog meat.

With the legislative initiatives above, the relevant political actors reacted to the pressure for change resulting from the cultural shift. However, the failure of these initiatives indicates that the political arena was deeply ambivalent. The main reason is that the political actors faced a dilemma: The Meat Inspection Act regulated the killing of "slaughter animals" for consumption in general, and the law defined which animal species were included in this category. Dogs could have been removed from the institution's regulatory area without any other change in the law. However, this change would have had the risk that the definition of other "slaughter animals," such as horses and rabbits, would also have been culturally questioned. Consequently, the whole institution might have lost its legitimacy. The classification of animal species such as horses and rabbits as "slaughter animals" was not without controversy among the population, especially since the 1970s, when public discussion of the ethics of killing farm animals increased, which was triggered by new cultural ideas on animal rights (Midgley 1983; Regan 1983; Singer 1975). The question is whether the political actors considered this risk, and whether it was relevant to their actions.

The historical analyses show that relevant political actors, during the entire period investigated, were aware of this dilemma. It was frequently raised in parliamentary discussions and in the extensive correspondence within and between ministries as well as civil society. Several actors were worried that passing the bill might lead to an erosion of the fundamental cultural legitimation of slaughtering animals. The moral reasons given for prohibiting the killing of dogs for consumption - their close proximity to humans and the affection and solidarity of humans toward them-might be applied similarly to the relationship between humans and other "slaughter animals." 27

The objection to a morally justified ban on slaughter was first raised by the Bremen State Veterinary Authority in 1951. The government agency argued that with "the same right one could, consequently, also demand a prohibition for the slaughtering of horses, pigeons, lambs, etc., since many humans are equally sensitive to the slaughtering of these animals." ${ }^{28}$ The Federal Ministry of Agriculture, which was involved significantly in the later elaboration of the 1959 and

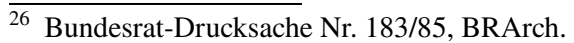

27 The four bills discussed here also included a ban on killing cats for human consumption.

${ }^{28}$ BArch, File B116/4630, letter from October 15, 1951.
} 
1963 bills, took over this position and expressed it to the Petitions Committee of the Bundestag, ${ }^{29}$ the Federal Minister of the Interior, ${ }^{30}$ the German Animal Welfare Association, ${ }^{31}$ the CDU/CSU parliamentary group, ${ }^{32}$ and numerous writers of protest letters. ${ }^{33}$ In an internal meeting of Federal Ministry of Agriculture employees, the participants emphasized that dogs and cats, as well as furred animals, and "in the true sense of the word, the horse" were not "slaughter animals"; however, officials saw the danger in a possible ban: "if this were done for dogs and cats, voices would rise demanding the same for the 'sweet, cute' lambs (little Easter lambs!), for the innocent, peaceful doves, for the 'noble animal and man's best friend,' the horse, etc., etc." 34 In a meeting with the Federal Press Office, a representative of the Federal Ministry of Agriculture also asked, "How does killing a dog or cat differ from slaughtering a pig or cattle?"35 This position was also publicly expressed by State Secretary Dr. Sonnemann during the Q\&A session of the Bundestag on April 29, 1954, ${ }^{36}$ and it was repeated in a meeting of the Bundestag Committee for Food, Agriculture and Forestry. ${ }^{37}$ Due to enormous pressure by the animal protection movement, and despite strong reservations, the German federal government introduced a bill in 1959 (Sebastian 2021). The Deutscher Städtebund (German Association of Cities) then contacted the Legal Committee of the Bundestag, which was responsible for issuing a statement, and argued that such a ban was not advisable "if the slaughter of other animals and the utilization of their meat for human consumption must remain permissible at the same time." 38 After the third bill was rejected, the Federal Ministry of Justice argued, in 1964, that questioning the moral legitimacy of slaughtering dogs by large segments of the population indicated an erosion of cultural popular support for killing animals for meat consumption in general. The ministry argued that therefore, the risk was high that a prohibition on killing dogs for meat consumption would lead to the public questioning the moral right to eat meat in general: "As a long-term goal, certain circles seem to have a ban on any 'arbitrary' killing

\footnotetext{
${ }^{29}$ BArch, File B116/4630, letter from January 28, 1954.

${ }^{30}$ BArch, File B116/4630, letter from February 23,1954.

31 BArch, File B116/4630, letter from February 24, 1954.

32 BArch, File B116/4630, letter from March 5, 1954.

33 For example, BArch, File B116/4630, letter from February 18, 1954.

34 BArch, File B116/4630, note from March 11, 1954.

35 BArch, File B116/4630, note from March 11, 1954.

${ }^{36}$ Protocol of the 26th Meeting of the 2nd German Bundestag, April 29, 1954, DBArch.

37 DBArch, File B116/4630, note from the 25th Meeting of the Bundestag Committee for Agriculture, June 22, 1954.

38 Letter from the Deutscher Städtetag to the Bundestag Legal Committee, July 4, 1960, BArch.
}

of certain animals (including horses, pigeons, and lambs) in mind." An outside expert brought in to advise the ministry warned that morally justified prohibition of the killing of dogs for consumption could be the "beginning of a certain recognition of the legal personality of the animal." 39

The risk of extending a ban on killing for consumption to other animals remained a central part of the discussion in the 1980s. Even before the Hessian bill was passed in the Bundesrat, the German government again discussed a possible ban on killing dogs. In a department meeting of the Federal Ministry of Youth, Family and Health, the Federal Ministry of Justice, and the Federal Ministry of Agriculture, officials argued that "an extension of the ban to all kinds of domestic animals must be feared." After the Hessian proposal was submitted, several Bundesrat committees dealt with it. The danger of extending the ban to other animals was discussed several times. In the Youth, Family and Health committee, a representative of the state of Bavaria considered that "there is a similar social relation with other animals, for example, riding horses. From an ethical point of view, a much more comprehensive examination of the entire problem would be necessary." 40

\section{Explanation with the approach "rejecting changing a part for fear of undermining the whole"}

These results support the theoretical assumptions of this paper, according to which the inconsistent pressure for change on the institution Meat Inspection Act confronts policy actors with a dilemma for action. On one hand, there was broad consensus that killing dogs for consumption could no longer be legitimized on a moral basis. On the other hand, abolishing the permission to kill dogs for this purpose might have opened a pathway to broad public questioning of the killing of other animals, possibly leading to questioning of meat consumption in general. The actors were aware that cultural objections to killing dogs could have easily been transferred to other types of slaughter animals. Therefore, the legitimacy of the institution Meat Inspection Act as a whole could be questioned. Most of the political actors would not have agreed with a cultural orientation that treats eating meat in general as amoral, and a prohibition on slaughtering other types of farm animals would have upset larger groups of voters and called into question the existence of the powerful meat industry. This finding also illustrates that the normative rationale for rejecting the bills was only the public face of the argument. Behind the curtain, the problem of "rejecting changing a part for fear

\footnotetext{
39 BArch, File, B141/403556, note from April 7, 1964.

40 Protocol of the 229th Meeting of the Bundesrat Committee for Youth, Family and Health, May 30, 1985, BRArch.
} 
of undermining the whole" motivated politicians to reject the bills.

This dilemma shows why the political action was contradictory: There were several initiatives among the political actors for institutional change that aimed to abolish the possibility of killing dogs for meat consumption, but relevant actors repeatedly prevented this institutional change. These contradictions are also indicated by the justifications political actors offered to explain why the initiatives for institutional change were not successful.

- Approval for the legislative change in the first and third bills was refused on the grounds that they were not farreaching enough. It is not understandable, however, why there were no immediate initiatives for more far-reaching regulations.

- The second bill was not put to vote because it was proposed late in the legislative period, and the committee delayed their statement too long. One could conclude from this explanation that the bill was not particularly pressing in the view of the committee members.

- Regarding the fourth bill, in explaining its rejection, the risk that the abolition of the slaughter of dogs could have led to questioning of the legitimacy of the slaughter of animals as a whole was addressed directly.

\section{Can we explain institutional persistence with path dependency based on increasing returns?}

This section examines how far the persistence of the institution can be explained through a self-reinforcing process of "increasing returns." Such a process does not exist in the case of the Meat Inspection Act. The institutional regulations on the killing of dogs no longer had any practical relevance, as eating dogs was no longer popular. As discussed above, the extent of dog meat consumption and the killing of dogs for meat is difficult to assess exactly, but it was low in the 1950s and almost unheard of in the 1980s. For example, media articles in 1954 reported only on a few butchers who slaughtered dogs. ${ }^{41}$ There were no other institutions related to this one, such as training regulations, or a specific slaughterhouse system. Therefore, there is no reason to assume that any relevant group of actors would have considered the benefits of maintaining permission to slaughter dogs to be higher than the costs of its abolition, in the sense of the utilitarian approach to path dependency. For this reason, it is also not plausible to assume that permission to slaughter dogs would have been functional for the system of institutions linked to it. As the institution was almost irrelevant to practice, it cannot be explained by the fact that actors held on to it for power interests. Ultimately, it is also not plausible to assume that relevant actors maintained permission to slaughter dogs because they considered it legitimate. Instead, there is strong evidence that no political actor considered permission to slaughter dogs to still be morally legitimate. Therefore, essential arguments based on the concept of path dependency do not apply in this case, or they are not specific enough.

\section{Can we explain institutional persistence through the party preferences theory?}

The analysis showed that the role of the governing parties does not contribute to our understanding of institutional persistence in this case. According to this approach, one would have to assume that political party differences trigger a blockade attitude of a certain faction in parliament or in a government coalition. However, among the four initiatives examined, which were all unsuccessful, two were introduced by the German federal government (1959, CDU/ CSU; 1963, CDU/CSU and FDP), and one by a party in the governing coalition (1954, the German Party). In only one case, the bill was introduced by the government of one of the German federal states ("Länder") and therefore, from outside the federal government (1985, SPD). Although the individual motivations of the decision-makers in each case cannot be reconstructed based on the data, it seems evident that all of the legislative proposals introduced responded to the public debate about the illegitimacy of killing dogs for meat production. All political parties in the parliament agreed that there was fundamental cultural legitimacy for the proposed ban. This is striking, as the policies of the conservative CDU/CSU parliamentary party were closely related to those of the agricultural sector, and one might have expected that the party would have been more reserved about a demand to restrict the meat industry. Neither the economically liberal FDP faction nor the social democrats (SPD) had any politically motivated objections to the ban. As has been shown, the reasons for rejecting the bills were based on the reservations of the parliamentary committee members in particular, but these committee members did not question the fundamental cultural legitimacy of the requirement based on their respective political backgrounds. Overall, no political opposition to the proposed legislation based on parties' political positions can be identified. Therefore, the differences in the political preferences of the governing parties do not contribute to the explanation of the rejection of the bills.

$\overline{41}$ Bild-Zeitung, January 16, 1954, No. 13, p. 1, "Bild zeigt ein trauriges Dokument: Hundeschlächter bei der Arbeit.“ 


\section{Discussion}

The findings of the case study show that cultural change led to strong pressure on the institution that allowed the killing of dogs for meat consumption, the Meat Inspection Act, based on changes in public opinion and the activities of civil society organizations. Despite four political initiatives for legal change, pressure to which the political actors reacted, the institution remained stable over three decades.

The theoretical approach of this paper is supported by the findings of the case study. They show that it is possible that the pressure resulting from cultural change affected only a part of the institutional regulations, in this case, the regulation related to the killing of dogs. However, the institution as a whole was not questioned. In the case study, all main political actors agreed that the moral basis for killing dogs for consumption no longer existed. However, the uneven cultural pressure on the institution caused a dilemma for the political actors. There was a risk that abolishing the right to kill dogs for consumption would lead to erosion of the legitimacy for slaughtering other species in the "slaughter animals" category, thus, to questioning of the moral legitimacy of the institution as a whole. Therefore, the action in the political arena was contradictory over three decades. The government and the main political parties publicly showed strong efforts to abolish this section of the law. However, "behind the curtain," parts of the relevant political actors (most importantly, employees of the ministries and members of the parliamentary committees) prevented the legislation from changing.

It was also shown that other explanatory approaches are not convincing. The explanation based on the path dependency approach, which essentially argues that institutional persistence is caused by increasing returns, does not do justice to the case, because there are no groups of actors who, for cost-benefit considerations, functional reasons, power interests, or legitimacy reasons, had an interest in maintaining the existing regulation for slaughtering dogs. The party preference theory also does not provide a suitable basis for explaining the persistence of the institutional regulation, as all actors agreed that the prohibition was justified.

The explanatory power of the proposed approach becomes further evident when analyzing the reason for the success of the abolition of the institutional regulation. Shortly after the fourth legislative initiative failed in 1985, the Bundestag Committee for Youth, Family and Health recommended to the Bundestag that a ban on the killing of dogs be included in the meat inspection law. This initiative differed from the other four attempts in that it no longer argued morality based on the new cultural ideas that classified dogs solely as "pets." Instead, it used a "rational" argument that was agreed upon by the relevant political actors ${ }^{42}$ stating that the killing of dogs for meat production was associated with health risks for slaughterhouse employees. This decision was based on a statement from the German Federal Health Office confirming this risk. Members of the committee had contacted the Office with a request to help resolve the issue, and the statement can be understood as a "complacency report," drawn up on the committee's instructions (Sebastian 2021). A similar argument for other animals must be regarded as unpromising (and thus, less dangerous for policymakers), as in the case of the production of dog meat there is little basis for assuming that substantial health risks actually existed. Instead, it seems likely that the responsible authorities could simply deny such a particular health hazard in other cases.

On this basis, the Bundestag decided on December 5, 1985, to include the ban on killing dogs for consumption in the revised Meat Inspection Act that came into force on April 14, 1986. The fact that the new justification was given between the two relevant sessions only five months apart, and that no medical evaluation was presented, indicates that this justification was simply constructed to create a possibility to change the law without risking the erosion of the regulation of slaughtering animals as a whole. All political parties agreed with the shift of the act (the SPD, CDU/CSU, FDP, and the Greens).

Therefore, the political actors found a way out of the dilemma of action with a type of reform that Prado and Trebilcock (2018) call an "institutional bypass" by finding a justification that no longer placed the moral foundations for killing dogs for consumption at the center, and thus, no longer questioned the legitimacy of the slaughter of animals in general. Instead, the ban was achieved by the political actors agreeing on a "rational" justification that dogs were a special case in the "slaughter animals" category because their killing was associated with (alleged) health risks for slaughterhouse employees. This argument did not open the door for questioning of the institution as a whole, as the health-related reason was defined as a specific problem of dog meat, which would not be applied to other slaughter animals.

\section{Conclusion}

This paper attempted to answer the research question of how the long-term persistence of an institution can be explained although it is exposed to high pressure to change due to a cultural shift within the population. The paper introduces a new theoretical approach to the explanation, "rejecting

\footnotetext{
${ }^{42}$ Report of the Member of Parliament Wagner, Bundestag-Drucksache Nr. 10/4410, DBArch.
} 
changing a part for fear of undermining the whole." This approach can be applied to institutions that regulate how the elements that belong to a category framed by the institution can be treated, and which elements are assigned to the overall category. It is possible that only one of the elements covered by institutional regulations comes under pressure because of a cultural change in the population, not the institution as a whole. We assume that this situation can lead to a political dilemma for the relevant actors: changing an element of the institution under pressure may lead, in the longer run, to erosion of the institution as a whole. Consequently, the risk for a contradictory process in the political arena increases. Although the government and the main political parties publicly display strong efforts in reacting to pressure from public opinion and civil society movements, there are strong and successful efforts "behind the curtain" to prevent institutional change based on a moral argument. The results of the case study support the assumption that this theoretical approach can provide a suitable explanation for institutional persistence despite strong pressure for change. The institutional persistence in the present case was the result of the relevant actors' fear that the morally justified removal of dogs from the category of "slaughter animals" would have called into question the legitimacy of the institution of killing animals for consumption. It was only through the "institutional bypass" in the justification for the ban on killing dogs for consumption, which did not question the legitimacy of the institution as such, that the ban could finally be placed. It is also shown that the concept of path dependency and the party preference theory do not provide valid explanations.

Thus, this paper contributes to the theoretical discussion of and research on institutional change as well as the scholarly discussion of the renegotiation of the relationship between society and animals. The paper is innovative as it offers a new insight into the theory and research on historical institutionalism based on a new theoretical approach to the explanation of institutional persistence. It also makes an innovative contribution to the sociology of agriculture and food, as well as the sociology of human-animal relations based on theorizing and analyzing the conditions that can be relevant for change in the institutional framework that distinguishes between slaughter animals and other, more protected categories of animals. We suggest that our finding, according to which rational arguments can offer better chances for institutional change than moral arguments, might apply more generally to institutional change toward a higher level of animal rights and animal protection. We may conclude from these findings, for example, that approaches that aim to increase institutional protection and rights for farm animals may have a better chance of success if they use the "rational" argument that such measures would contribute to a reduction of $\mathrm{CO}_{2}$ emissions to combat climate change, instead of moral arguments.

\section{Appendix}

Relevant original documents:

Entwurf eines Gesetzes über das Verbot des Inverkehrbringens von Hunde- und Katzenfleisch [Draft law on the prohibition of the marketing of dog and cat meat.], April 1, 1954, https://dserver.bundestag.de/btd/02/004/0200415.pdf. Accessed July 20, 2021.

Entwurf eines Gesetzes über das Verbot des Schlachtens von Hunden und Katzen [Draft law on the prohibition of slaughter of dogs and cats], December 10, 1959, https:// dserver.bundestag.de/btd/03/014/0301485.pdf. Accessed July 20, 2021.

Entwurf eines Gesetzes über das Verbot des Schlachtens von Hunden und Katzen [Draft law on the prohibition of slaughter of dogs and cats], October 1, 1963, not available online, accessible via the Bundesrat Archives.

Entwurf eines Gesetzes über das Verbot des Schlachtens von Hunden und Katzen [Draft law on the prohibition of slaughter of dogs and cats], April 24, 1985, https://dserv er.bundestag.de/brd/1985/D183+85.pdf. Accessed July 20, 2021.

Gesetz zur Änderung des Fleischbeschaugesetzes [Act amending the law on meat inspection], April 13, 1986,

http://www.bgbl.de/xaver/bgbl/start.xav?startbk=Bunde sanzeiger_BGBl\&jumpTo=bgbl186s0398.pdf. Accessed July 20, 2021.

Acknowledgements We would like to thank Jürgen Beyer (University of Hamburg), Patricia Frericks (University of Kassel), Peter Niesen (University of Hamburg), the three anonymous reviewers and the editor, Matthew Sanderson, for their very helpful and constructive comments and suggestions on earlier drafts of this article. We also thank Scribendi for the editing of the article.

Funding Open Access funding enabled and organized by Projekt DEAL.

Open Access This article is licensed under a Creative Commons Attribution 4.0 International License, which permits use, sharing, adaptation, distribution and reproduction in any medium or format, as long as you give appropriate credit to the original author(s) and the source, provide a link to the Creative Commons licence, and indicate if changes were made. The images or other third party material in this article are included in the article's Creative Commons licence, unless indicated otherwise in a credit line to the material. If material is not included in the article's Creative Commons licence and your intended use is not permitted by statutory regulation or exceeds the permitted use, you will need to obtain permission directly from the copyright holder. To view a copy of this licence, visit http://creativecommons.org/licenses/by/4.0/. 


\section{References}

Archer, Margaret S. 1996. Culture and Agency. The Place of Culture in Social Theory. Cambridge: Cambridge University Press.

Arluke, Arnold. 2006. Just a dog. Understanding Animal Cruelty and Ourselves. Philadelphia: Temple University Press.

Allan, James P., and Lyle Scruggs. 2004. Political partisanship and welfare state reform in advanced industrial societies. American Journal of Political Science 48 (3): 496-512.

Arthur, W. Brian. 1994. Increasing returns and path dependence in the economy. Ann Arbor: University of Michigan Press.

Beach, Derek, and Rasmus Brun Pedersen. 2013. Process-tracing methods: Foundations and guidelines. Ann Arbor: University of Michigan Press.

Béland, Daniel. 2009. Ideas, institutions, and policy change. Journal of European Public Policy 16 (5): 701-718.

Beyer, Jürgen. 2010. The same of not the same. On the variety of mechanisms of path dependence. International Journal of Social Sciences, 5(1): 1-11.

Blouin, David D. 2012. Understanding relations between people and their pets. Sociology Compass 6 (11): 856-869.

Börzel, Tanja A., and Thomas Risse. 2009. Revisiting the nature of the Beast-politicization, European identity, and postfunctionalism: A comment on Hooghe and Marks. British Journal of Political Science. 39 (1): 217-220.

Cao, Deborah and Steven White. 2016. Studies in Global Animal Law. Heidelberg and other: Springer.

Capano, Giuliano. 2009. Understanding policy change as an epistemological and theoretical problem. Journal of Comparative Policy Analysis 11 (1): 7-31.

Danielson, Taylor and Robin Stryker. 2015. Cultural influences on social policy development. In The Oxford handbook of U.S. social policy, eds. Daniel Béland, Christopher Howard, and Kimberley J. Morgan, 134-150. New York: Oxford University Press.

David, Paul A. 1985. Clio and the economics of QWERTY. American Economic Review 75 (2): 332-337.

Ebbinghaus, Bernhard. 2005. Can path dependence explain institutional change? Two approaches applied to welfare state reform, MPIfG Discussion Paper 05/2, Max-Planck-Institut für Gesellschaftsforschung, Köln

Esping-Andersen, Gösta. 1990. Three Worlds of Welfare Capitalism. Oxford: Polity Press.

Franklin, Adrian. 1999. Animal and Modern Cultures. London: Sage Publications.

Frericks, Patricia. 2017. "Machinery" or "spirit" of the welfare state: Institutional change as institutional inertia. International Journal of Sociology and Social Policy 37(5,6): 341-352.

Geppert, Pia. 1990. "Hundeschlachtungen in Deutschland im 19. und 20. Jahrhundert unter besonderer Berücksichtigung der Verhältnisse in München“. Dissertation, University of Munich.

Gingrich, Jane R. 2011. Making markets in the welfare state: The politics of varying market reforms. Cambridge: Cambridge University Press.

Grier, Katherine C. 2006. Pets in America. Chapel Hill: University of North Carolina Press.

Häusermann, Silja, Georg Picot, and Dominik Geering. 2013. Review article: Rethinking party politics and the welfare state-Recent advances in the literature. British Journal of Political Science 43 (1): 221-240.

Hall, Peter. 1993. Policy paradigms, social learning, and the state. The case of economic policy making in Britain. Comparative Politics 25 (3): 275-296.

Hall, Peter A., and Rosemary C. R. Taylor. 1996. Political Science and the Three Institutionalisms. Political Studies 44: 936-957.
Hibbs, Douglas A. 1977. Political parties and macroeconomic policy. American Political Science Review 71 (4): 1467-1487.

Li, Peter J., Jiang Sun, and Dezhi Yu. 2017. Dog "Meat" Consumption in China. A Survey of the Controversial Eating Habit in Two Cities. Society \& Animals 25(6): 513-532.

Mahoney, James. 2000. Path Dependence in Historical Sociology. Theory and Society 29 (4): 507-548.

Mai, Günther. 2007. Die Agrarische Transition. Agrarische Gesellschaften in Europa und die Herausforderungen der industriellen Moderne im 19. und 20. Jahrhundert. Geschichte und Gesellschaft 33(4): 471-514.

Midgley, Mary. 1983. Animals and Why They Matter. Athens: University of Georgia Press.

Morgan, Karen J., and Matthew Cole. 2011. The discursive representation of nonhuman animals in a culture of denial. In Humans and Other Animals: Critical Perspectives, ed. Bob Carter and Nickie Charles, 112-132. London: Palgrave.

North, Douglass C. 1990. Institutions, institutional change and economic performance. Cambridge: Cambridge University Press.

Ogburn, William F. 1964. On Culture and Social Change. Chicago: University of Chicago.

Oh, Minjoo and Jeffrey Jackson. 2011. Animal Rights vs. Cultural Rights: Exploring the Dog Meat Debate in South Korea from a World Polity Perspective. Journal of Intercultural Studies 32(1): 31-56.

Peters, Anne, ed. 2020. Studies in Global Animal Law. Berlin: Springer Open.

Pfau-Effinger, Birgit. 2005. Culture and Welfare State Policies: Reflections on a Complex Interrelation. Journal of Social Policy 34 (1): $1-18$.

Pierson, Paul. 2001. The new politics of the welfare state. Oxford, New York: Oxford University Press.

Pluda, Martina. 2019. Animal law in the Third Reich. Barcelona: Servei de Publicacions de la Universitat Autònoma de Barcelona.

Prado, Mariana M., and Michael J. Trebilcock. 2018. What Is an Institutional Bypass? In Institutional Bypasses: A Strategy to Promote Reforms for Development, ed. Mariana M. Prado and Michael J. Trebilcock, 27-46. Cambridge: Cambridge University Press.

Regan, Tom. 1983. The Case for Animal Rights. London: Routledge.

Rueschemeyer, Dietrich. 2003. Can one of a few cases yield theoretical gains? In Comparative historical analysis in the social sciences, ed. James Mahoney and Dietrich Rueschemeyer, 305-336. Cambride: Cambride University Press.

Schmidt, Vivian A. 2002. Does Discourse matter in the politics of welfare state adjustment? In: Comparative Political Studies 35 (2): 168-193.

Sebastian, Marcel. 2019. Subjekt oder Objekt? Ambivalente gesellschaftliche Mensch-Tier-Beziehungen als Resultat kultureller Aushandlungs- und Wandlungsprozesse. In Haben Tiere Rechte? Schriftenreihe der Bundeszentrale für Poltische Bildung, eds. Elke Diehl, and Jens Tuider, 69-81, Bonn: Bundeszentrale für politische Bildung.

Sebastian, Marcel. 2021. The influence of social movements on policy change: Delayed success in banning dog slaughter in Germany. Social Movement Studies. Online first. https://doi.org/10.1080/ 14742837.2021.1967126

Singer, Peter. 1975. Animal Liberation. New York: Harper Collins.

Steensland, Brian. 2006. Cultural categories and the American welfare state: The case of Guaranteed Income Policy. American Journal of Sociology 111 (5): 1273-1326.

Stucki, Saskia. 2017. (Certified) Humane Violence? Animal Welfare Labels, the Ambivalence of Humanizing the Inhumane, and What International Humanitarian Law Has to Do with It. American Journal of International Law 111: 277-281. 
Trampusch, Christine, and Bruno Palier. 2016. Between X and Y: How process tracing contributes to opening the black box of causality. New Political Economy 21 (5): 437-454.

Wills, Joe. 2020. The legal regulation of non-stun slaughter: Balancing religious freedom, non-discrimination and animal welfare. Liverpool Law Review 41: 145-171.

Wise, Steven M. 2003. The Evolution of Animal Law since 1950. The Humane Society Institute for Science and Policy. WBI Studies Repository, online: https://www.wellbeingintlstudiesrepository. org/cgi/viewcontent.cgi?article $=1005 \&$ context=sota_2003 (last checked June 7, 2021)

Publisher's Note Springer Nature remains neutral with regard to jurisdictional claims in published maps and institutional affiliations.
Birgit Pfau-Effinger is Research Professor for Sociology of Cultural and Institutional Change at the Department of Social Sciences at the University of Hamburg (Germany). Her main research interests include historical and cross-national comparative research about culture and welfare states, labor markets, family policies, gender and the workfamily relationship, and the cultural and institutional context of the society-animal relationship. She has published numerous articles in international scientific journals and published books with international publishers of high reputation.

Marcel Sebastian is a post-doctoral researcher and member of the Group for Society and Animals Studies at the University of Hamburg. His research interests include the sociology of human-animal relations, social movement studies, historical new institutionalism, and the transformation of social relations with nature. 